\title{
Prevalence and clinical profile of microcephaly in South America pre-Zika, 2005-14: prevalence and case-control study
}

\author{
lêda M Orioli, ${ }^{1,2}$ Helen Dolk, ${ }^{3}$ Jorge S Lopez-Camelo, ${ }^{2,4}$ Daniel Mattos, ${ }^{1,2}$ Fernando A Poletta, ${ }^{2,4}$ \\ Maria G Dutra, ${ }^{2,5}$ Flavia M Carvalho, ${ }^{2,5}$ Eduardo E Castilla ${ }^{2,4}$
}

${ }^{1}$ Latin American Collaborative

Study of Congenital

Malformations (ECLAMC)

at Department of Genetics,

Institute of Biology, Federal

University of Rio de Janeiro,

21944-001, Rio de Janeiro,

Brazil

${ }^{2}$ National Institute of Population

Medical Genetics (INAGEMP),

Porto Alegre, Brazil

${ }^{3}$ Maternal Fetal and Infant

Research Centre, Institute

of Nursing and Health

Research, Ulster University,

Newtownabbey, Northern

Ireland, UK

${ }^{4}$ ECLAMC at Center for Medical

Education and Clinical Research (CEMIC-CONICET), Buenos Aires,

Argentina

${ }^{5}$ ECLAMC at Laboratory of

Congenital Malformations

Epidemiology, Instituto

Oswaldo Cruz, Fundação

Oswaldo Cruz (FIOCRUZ), Rio de

Janeiro, Brazil

Correspondence to: I M Orioli

orioli@centroin.com.br

Additional material is published online only. To view please visit the journal online.

Cite this as: BMJ 2017;359:j5018 http://dx.doi.org/10.1136/bmj.j5018

Accepted: 19 October 2017

\section{ABSTRACT}

OBJECTIVE

To describe the prevalence and clinical spectrum of microcephaly in South America for the period 2005-

14 , before the start of the Zika epidemic in 2015, as a baseline for future surveillance as the Zika epidemic spreads and as other infectious causes may emerge in future.

\section{DESIGN}

Prevalence and case-control study.

DATA SOURCES

ECLAMC (Latin American Collaborative Study of Congenital Malformations) database derived from 107 hospitals in 10 South American countries, 2005 to 2014. Data on microcephaly cases, four nonmalformed controls per case, and all hospital births (all births for hospital based prevalence, resident within municipality for population based prevalence). For 2010-14, head circumference data were available and compared with Intergrowth charts.

\section{RESULTS}

552 microcephaly cases were registered, giving a hospital based prevalence of 4.4 (95\% confidence interval 4.1 to 4.9$)$ per 10000 births and a population based prevalence of 3.0 (2.7 to 3.4) per 10000 . Prevalence varied significantly between countries and between regions and hospitals within countries. Thirty two per cent $(n=175)$ of cases were prenatally diagnosed; $29 \%(n=159)$ were perinatal deaths. Twenty three per cent $(n=128)$ were associated with a diagnosed genetic syndrome, 34\% $(n=189)$ polymalformed without a syndrome diagnosis, $12 \%$ $(n=65)$ with associated neural malformations, and $26 \%(n=145)$ microcephaly only. In addition, 3.8\% $(n=21)$ had a STORCH (syphilis, toxoplasmosis, other including HIV, rubella, cytomegalovirus, and

\section{WHAT IS ALREADY KNOWN ON THIS TOPIC}

A surge in microcephaly was detected in Brazil at the end of 2015 followed by other South American countries as the Zika virus spread throughout the continent

However, inconsistent definition and registration of this congenital anomaly clouded estimation of the magnitude of increase due to Zika virus

\section{WHAT THIS STUDY ADDS}

This study provides baseline prevalence for microcephaly in 10 South American countries in the pre-Zika period, with which prevalence during the Zika epidemic can be compared

The role of other infectious and non-infectious causes should not be ignored even in times of Zika epidemic

These data can assist both researchers and governments in coping with the Zika induced microcephaly problem herpes simplex) infection diagnosis and $2.0 \%(n=11)$ had consanguineous parents. Head circumference measurements available for $184 / 235$ cases in 201014 showed $45 \%(n=82)$ more than 3 SD below the mean, $24 \%(n=44)$ between 3 SD and 2 SD below the mean, and $32 \%(n=58)$ larger than -2 SD.

\section{CONCLUSION}

Extrapolated to the nearly 7 million annual births in South America, an estimated 2000-2500 microcephaly cases were diagnosed among births each year before the Zika epidemic began in 2015 . Clinicians are using more than simple metrics to make microcephaly diagnoses. Endemic infections are important enduring causes of microcephaly.

\section{Introduction}

After an increase in the number of babies born with congenital microcephaly was observed in northeast Brazil in 2015 and French Polynesia in 2013-14 following epidemics of the Zika flavivirus in these populations, ${ }^{12}$ the World Health Organization declared a public health emergency of international concern (now no longer in force) as further global spread of the virus was predicted. ${ }^{3}$ The aim of a diagnosis of microcephaly at birth is to use small head circumference as an indicator of a high risk of having experienced poor in utero development of the brain. ${ }^{4}$ Microcephaly is known to be caused by viral, bacterial, and parasitic infections such as rubella, cytomegalovirus, herpes simplex virus, immunodeficiency virus, toxoplasmosis, and syphilis among others ${ }^{5-9}$ (as well as many noninfectious causes), so that an infectious cause of the observed increase in affected babies was plausible. Since then, more evidence has been accumulating to support a causal link, ${ }^{10} 11$ including the neurotropic nature of the Zika virus and preliminary reports of epidemiological controlled studies. ${ }^{12-14}$ However, the size of the risk for infected pregnant women remains unclear, and the extent of the estimated increase in microcephaly in northeast Brazil has not yet been observed in other populations affected by Zika.

Infection with the Zika virus in pregnancy has also been reported with other brain anomalies, ocular manifestations, arthrogryposis, and intrauterine growth retardation in the newborn. ${ }^{13}$ 15-18 These observations are leading to a broader definition of "congenital Zika syndrome"19-28 in a similar way to the well established congenital rubella syndrome. ${ }^{29}$ Zika may cause a wider spectrum of abnormalities of the brain, ${ }^{13} 30$ which may be diagnosed only later in infancy or childhood. Microcephaly itself may become manifest later owing to restricted postnatal head growth. ${ }^{15}$ 
The definition of microcephaly is not uniform in the medical literature. ${ }^{4}$ Birth defect surveillance systems in Europe and the United States have noted registration to be poorly standardised, ${ }^{3132}$ probably owing to the lack of an agreed definition. ${ }^{4}$ The "metric" microcephaly definition (how small a head size is considered microcephalic) has changed several times in response to the Zika epidemic. ${ }^{33}$

ECLAMC (Latin American Collaborative Study of Congenital Malformations) is a case-control, hospital based congenital anomaly surveillance system in Latin America (Central and South America), which has been operating since $1967 .{ }^{34}$ Here, we describe the prevalence and clinical spectrum of microcephaly in South America for the period 2005-14, before the start of the Zika epidemic in 2015, as a baseline for future surveillance as the Zika epidemic spreads and as other infectious causes may emerge in future.

\section{Methods}

Description of population and ECLAMC data

Between 2005 and 2014, 107 hospitals (fig 1 and supplementary table) belonging to the ECLAMC network in 10 South American countries (Argentina,

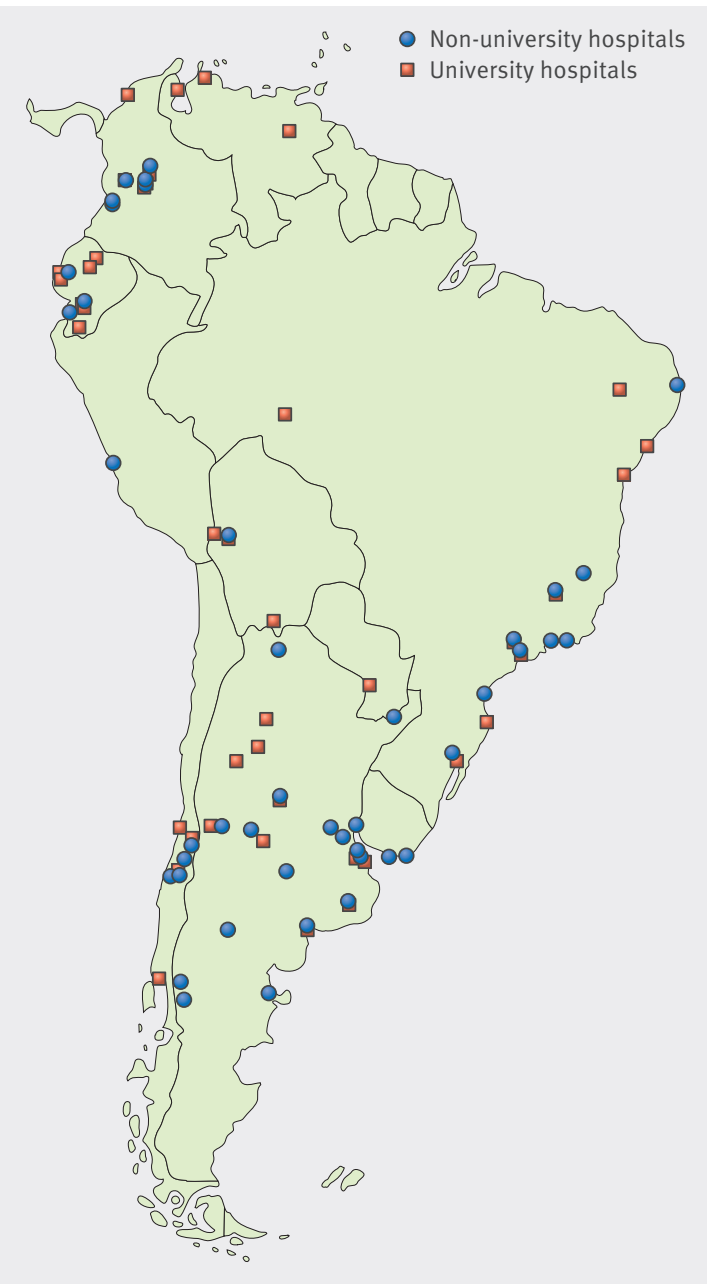

Fig 1 | Map of 107 hospitals in ECLAMC 2005-14. Hospital codes are given in supplementary table
Bolivia, Brazil, Chile, Colombia, Ecuador, Paraguay, Peru, Uruguay, and Venezuela) registered congenital anomalies in a total of 1247185 births. Data from Central America were not available for this period in ECLAMC. The study period predates the Zika epidemic, which started in 2015. During the 2005-14 period, participation in the ECLAMC network declined, so that 46 of the 107 hospitals were participating by 2010. Fifty seven of the hospitals were university hospitals (supplementary table), and there were also some non-university tertiary referral hospitals. Tertiary hospitals typically serve the local area while also receiving referrals of high risk pregnancies and pregnancies in which malformations have been diagnosed prenatally.

All babies, live and stillborn, with congenital anomalies are registered. Termination of pregnancy for fetal anomaly was illegal during the study period (until 2014) in all countries, except under certain very restricted conditions that would not be specifically relevant to microcephaly.

In each hospital, the paediatrician diagnoses the congenital anomalies and enters the data by choosing the diagnosis from an electronic list, which is coded automatically to ICD-8 (international classification of disease, version 8) codes with a two digit ECLAMC extension for further specification and laterality. This information is transmitted to the ECLAMC central database. All diagnostic information is collected from the maternity unit up to but not beyond discharge.

For each malformed baby born in the hospital, a liveborn non-malformed control is chosen as the next birth of the same sex in the same hospital. If the next birth is not available, the subsequent birth is selected (17.5\% of controls). The participation rate in ECLAMC hospitals by mothers of both cases and controls is very high. The mothers of both cases and controls are interviewed by the ECLAMC paediatrician (usually) or by a designated nurse or medical student, depending on hospital, before they are discharged from the maternity unit, according to a standard interview schedule described elsewhere. ${ }^{34}$ A data entry programme is accessed via a secure internet portal to the ECLAMC server. Before 2010 data entry was by palm held device and transmitted electronically.

The information collected from medical records for the malformed baby includes the diagnosis, whether the malformation was diagnosed prenatally, gestational age, and birth weight. The information collected from maternal interviews and analysed in this paper includes consanguinity (up to second cousin), exposure to STORCH (syphilis, toxoplasmosis, other including HIV, rubella, cytomegalovirus, and herpes simplex), influenza, diabetes, and demographic information such as residence of the mother, maternal age, and maternal education. Death in the first three days (by the time of data collection) was recorded. "Perinatal deaths" as used in this paper is the addition of stillbirths and deaths in the first three days of life. Each hospital 
collects a limited set of data on all births delivered in the hospital, including the total number of live births and stillbirths for calculation of prevalence.

\section{Definition and classification of microcephaly}

The ECLAMC operational manual defines microcephaly (ICD-8 code 743.1) as head circumference more than $3 \mathrm{SD}$ below the mean ( $-3 \mathrm{SD}$ ) for gestational age and sex; any other criteria used instead by hospitals should be specified as part of the diagnostic text. The ECLAMC manual does not specify the growth chart to be used by hospitals, and nor has this been specified in the diagnostic text given by paediatricians. ECLAMC protocols are reinforced by annual meetings of ECLAMC paediatricians, but the specific question of standardisation of the definition and diagnosis of microcephaly did not come up during the study period. This paper includes any diagnosis of microcephaly made by paediatricians, whether or not its diagnosis follows the ECLAMC head circumference recommendation.

Head circumference data are requested to be added to the ECLAMC data for any baby with microcephaly, collected as additional text, but these data were accessible for analysis only from 2010 when data entry was by internet portal. For the purposes of this research, we converted all available head circumference data from 2010 on, when gestational age and sex had also been specified, to $\mathrm{z}$ scores (specific to gestational age and sex) according to the Intergrowth charts for very preterm and preterm/term babies by using the International Standards for Size at Birth app (v1.0.5934.26288). ${ }^{35}$ As gestational age is recorded in completed weeks, we used the Intergrowth modelled estimates for each gestational week+3 days. The slight discontinuity in the Intergrowth models for very preterm and preterm/term babies giving a higher growth rate at 33 weeks was not smoothed. Birth weight was also classified to $\mathrm{z}$ scores by the same Intergrowth charts for 2005-14.

A clinical geneticist (IMO), working centrally on the basis of the diagnostic codes and text descriptions given by the hospital paediatrician (syndromes were diagnosed by the paediatricians, not centrally), further classified microcephaly cases as follows. (A) Syndromes-A1 genetic syndromes (A1.1 chromosomal and A1.2 monogenic syndromes); A2-embryopathies (teratogenic/environmental syndromes).

Polymalformed microcephaly-microcephaly with other major non-neural malformations excluding A. (C) Microcephaly with associated malformations of neural origin (brain, spinal cord, ocular) excluding cases classified to A or B. (D) Isolated microcephalyonly microcephaly coded, or microcephaly with minor additional anomalies.

Categories $\mathrm{C}$ and $\mathrm{D}$, with the addition of cases from category A in which no major non-neural associated anomalies existed (shown in the last column of table 1), were further analysed together as "neural only cases." Analysis of "neural only cases," similar to microcephaly now associated with Zika, ${ }^{22}$ would show the frequency of causative factors associated with such a phenotype in a non-Zika period. However, genetic syndromes or embryopathies (category A) may be underrepresented as they include only those diagnosed in the first few days of life (some microcephaly cases may have received syndrome diagnoses later than this). All cases and controls with STORCH infections had laboratory confirmed evidence of infection. Cases had in addition a STORCH embryopathy diagnosis (classified to A2 above) given by the paediatrician at the hospital. Some brain imaging and genetic syndrome diagnoses for microcephaly cases may be missing if they became available after discharge from the maternity unit. We specifically analysed the presence of arthrogryposis, as it is emerging as part of the definition of congenital Zika syndrome. ${ }^{1718}$

\section{Statistical analysis}

We calculated prevalence of microcephaly as the number of cases of microcephaly (live and stillborn) divided by the total number of births, and expressed it per 10000 births. ${ }^{36}$ We calculated two estimates for regions and countries-a hospital based estimate and a population based estimate. The hospital based estimate included all cases born in the participating hospitals, with a denominator of all births in the participating hospitals. As some of the participating hospitals are tertiary centres that attract high risk pregnancies or prenatally diagnosed cases, the population based estimate included only babies with microcephaly to residents of the same municipality as the hospital, with a denominator estimated as the number of births multiplied by the proportion of controls (controls of all malformed babies in the same year) who were resident in the same municipality as the hospital.

We used a multilevel Poisson random effects model to analyse secular trend in prevalence. Prevalence by region and country are shown with Poisson exact 95\% confidence intervals. We analysed case-control data by conditional logistic regression with matching variables of year, hospital, and sex. For this study, to improve statistical power, we used the microcephaly matched control as well as the three subsequent non-malformed controls chosen for babies with other malformations in the same hospital and year and of the same sex. Odds ratios were adjusted for maternal age and maternal education. We analysed odds ratios for all microcephaly cases and for all neural only cases. We used Stata 12 statistical software for all analyses. The sample size of the primary case-control study allows identification of a twofold risk factor for an exposure frequency of 5\% with a test power of $70 \%$ and a significance level of $5 \%$, or an odds ratio greater than 4 with a risk factor prevalence of $1 \%$.

\section{Extrapolation to South America}

We extrapolated our prevalence results to all 6.8 million births in South America (2016 estimate from www.worldpopdata.org), using both a simple estimate (the population based prevalence applied to all births in South America) and a country stratified 


\begin{tabular}{|c|c|c|c|c|c|c|}
\hline Clinical classification & $\begin{array}{l}\text { All microcephaly } \\
\text { cases }\end{array}$ & $\begin{array}{l}\text { Prevalence } \\
\text { (per } 10000)\end{array}$ & $\begin{array}{l}\text { Male/female } \\
\text { sex ratio }\end{array}$ & $\begin{array}{l}\text { Prenatally } \\
\text { diagnosed cases }\end{array}$ & $\begin{array}{l}\text { Perinatal } \\
\text { deaths* }\end{array}$ & $\begin{array}{l}\text { Neural only } \\
\text { cases }\end{array}$ \\
\hline A1.1. Chromosomal syndromes: & $68(12.3)$ & 0.55 & 0.51 & $30(44)$ & $52(76)$ & 0 \\
\hline Patau & 41 & & & & & \\
\hline Edwards & 14 & & & & & \\
\hline Other chromosomal anomaly & 8 & & & & & \\
\hline Down & 3 & & & & & \\
\hline Turner & 1 & & & & & \\
\hline $5 \mathrm{p}$ - deletion & 1 & & & & & \\
\hline A1.2. Monogenic syndromes: & $60(10.9)$ & 0.48 & 0.78 & $29(48)$ & $22(37)$ & $2(3)$ \\
\hline Holoprosencephalyt & 36 & & & & & \\
\hline Meckel & 5 & & & & & \\
\hline Skeletal dysplasia & 3 & & & & & \\
\hline Penna-Shokeir I & 3 & & & & & \\
\hline Seckel & 3 & & & & & \\
\hline Crouzon & 2 & & & & & \\
\hline Ictiosis & 2 & & & & & \\
\hline Cornelia de Lange & 1 & & & & & \\
\hline Treacher Collins & 1 & & & & & \\
\hline Freeman-Sheldon & 1 & & & & & \\
\hline Acrocallosal & 1 & & & & & \\
\hline Dominant lissencephaly & 1 & & & & & \\
\hline Ivemark & 1 & & & & & \\
\hline A2. Embryopathies: & $25(4.5)$ & 0.20 & 0.67 & $4(16)$ & $3(12)$ & $18(72)$ \\
\hline Embryopathy cytomegalovirusł & 9 & & & & & \\
\hline Embryopathy toxoplasmosis $\neq$ & 4 & & & & & \\
\hline Brain disruption with dead twin & 2 & & & & & \\
\hline Embryopathy alcohol & 2 & & & & & \\
\hline Embryopathy syphilis $\ddagger$ & 2 & & & & & \\
\hline Embryopathy rubellał & 2 & & & & & \\
\hline Embryopathy HIV+syphilisł & 1 & & & & & \\
\hline Embryopathy HIV+toxoplasmosisł & 1 & & & & & \\
\hline Embryopathy syphilis+toxoplasmosisł & 1 & & & & & \\
\hline Embryopathy rubella+syphilis $\neq$ & 1 & & & & & \\
\hline B. Polymalformed without syndrome diagnosis & $189(34.2)$ & 1.52 & 0.89 & $63(33)$ & $67(35)$ & 0 \\
\hline $\begin{array}{l}\text { C. Microcephaly with associated malformations } \\
\text { of neural origin: }\end{array}$ & $65(11.8)$ & 0.52 & 0.91 & $31(48)$ & $5(8)$ & $65(100)$ \\
\hline Encephalocele & 13 & & & & & \\
\hline Brain necrosis/calcification & 9 & & & & & \\
\hline $\begin{array}{l}\text { Hydrocephaly with calcifications, neuronal } \\
\text { migration, or other brain anomalies }\end{array}$ & 9 & & & & & \\
\hline Neuronal migration abnormality & 7 & & & & & \\
\hline Corpus callosum anomaly & 5 & & & & & \\
\hline Spina bifida & 4 & & & & & \\
\hline Cerebellar anomaly & 4 & & & & & \\
\hline Hydrocephaly & 4 & & & & & \\
\hline Hydranencephaly & 4 & & & & & \\
\hline Other brain defects & 4 & & & & & \\
\hline An/cryptophthalmos & 1 & & & & & \\
\hline Corneal opacity & 1 & & & & & \\
\hline D. Isolated microcephaly & $145(26.3)$ & 1.16 & 0.56 & $18(12)$ & $10(7)$ & $145(100)$ \\
\hline Total microcephaly cases & $552(100.0)$ & 4.43 & 0.72 & $175(31.7)$ & $159(28.8)$ & $230(41.7)$ \\
\hline
\end{tabular}

*Stillbirths and deaths in the first three days of life.

tAll holoprosencephaly without chromosomal syndrome or embryopathy were attributed to monogenic category whether or not monogenic, digenic, or copy number variation syndrome diagnosis was made.

‡STORCH (syphilis, toxoplasmosis, other including HIV, rubella, cytomegalovirus, and herpes simplex) embryopathies: six STORCH cases had other major congenital anomalies, four of which were heart defects.

estimate (the country specific, population based prevalence applied to each participating country's annual births).

\section{Patient involvement}

No patients were involved in setting the research question or the outcome measures, nor were they involved in developing plans for recruitment, design, or implementation of the study. No patients were asked to advise on interpretation or writing up of results.
There are no plans to disseminate the results of the research to study participants or the relevant patient community.

\section{Results}

\section{Prevalence}

Five hundred and fifty two cases of microcephaly were recorded, a hospital based prevalence of 4.4 (95\% confidence interval 4.1 to 4.9 ) per 10000 births, including live births and stillbirths. Hospital 
based prevalence varied by country and by region (table 2). Variation between hospitals was significant $\left(\chi^{2}=950.5, \mathrm{df}=106 ; \mathrm{P}<0.001\right)$ and is shown in fig 2 for 56 hospitals with at least 5000 births. Seventy one per cent $(22408 / 31560)$ of controls and $49 \%(268 / 552)$ of cases were resident within the municipality of the hospital. The population based prevalence estimate was 3.0 (2.7 to 3.4) per 10000 births. Population based prevalence also varied by country and region (table 2). The highest prevalence was recorded in Brazil, specifically northeast and southeast Brazil, but the region of metropolitan Chile also recorded a high prevalence (table 2). One of the hospitals in Rio de Janeiro (southeast Brazil, hospital code A05; supplementary table) is a highly selective tertiary centre in the Rio municipality with an overall malformation rate of $22 \%$. The population based prevalence for Rio (see footnote to table 2) remains high, as Rio is a single municipality and there is further selection within municipality that cannot be corrected for; this explains some of the high prevalence in southeast Brazil. We found no significant secular trend in prevalence (prevalence rate ratio: linear term 0.99, $95 \%$ confidence interval 0.95 to 1.02 ; quadratic term $0.99,0.98$ to 1.00$)$.

The live birth hospital based prevalence of microcephaly (as a proportion of all live births) was 4.5 (3.9 to 4.9) per 10000; 1.2\% of all births were stillbirths, and as a proportion of all stillbirths the microcephaly prevalence was higher at 17.5 (16.9 to 18.1 ) per 10000. Overall, "perinatal mortality" was $29 \%$ among all microcephaly cases and $7 \%$ among neural only cases (table 3). Microcephaly or an associated congenital anomaly was prenatally diagnosed in $32 \%$ of all cases or $22 \%$ of neural only cases (table 3).

\begin{tabular}{|c|c|c|c|c|c|c|}
\hline \multirow[b]{2}{*}{ Country and region (No of hospitals) } & \multicolumn{3}{|c|}{ Hospital based } & \multicolumn{3}{|c|}{ Population based } \\
\hline & Cases & Total births & $\begin{array}{l}\text { Prevalence, per } \\
10000(95 \% \mathrm{Cl})\end{array}$ & Cases & Births & $\begin{array}{l}\text { Prevalence, per } \\
10000(95 \% \mathrm{Cl})\end{array}$ \\
\hline Argentina (35): & 95 & 316771 & $3.0(2.4$ to 3.7$)$ & 39 & 237702 & $1.6(1.2$ to 2.2$)$ \\
\hline Buenos Aires (9) & 17 & 53032 & $3.2(1.8$ to 5.1$)$ & 4 & 43420 & $0.92(0.25$ to 2.4$)$ \\
\hline Centro (2) & 13 & 33768 & $3.8(2.1$ to 6.6$)$ & 6 & 27793 & $2.2(0.79$ to 4.7$)$ \\
\hline Cuyo (5) & 3 & 31566 & $1.0(0.20$ to 2.8$)$ & 2 & 26609 & 0.75 (0.09 to 2.7$)$ \\
\hline Nordeste (1) & 2 & 17096 & $1.2(0.14$ to 4.2$)$ & 2 & 17096 & $1.2(0.14$ to 4.2$)$ \\
\hline Noroeste (4) & 36 & 92936 & $3.9(2.7$ to 5.4$)$ & 6 & 45718 & $1.3(0.48$ to 2.9$)$ \\
\hline Pampa (9) & 23 & 80233 & $2.9(1.8$ to 4.3$)$ & 18 & 68926 & $2.6(1.6$ to 4.1$)$ \\
\hline Patagonia (5) & 1 & 8140 & $1.2(0.03$ to 6.8$)$ & 1 & 8140 & $1.2(0.03$ to 6.8$)$ \\
\hline Bolivia (5): & 18 & 80322 & $2.2(1.3$ to 3.5$)$ & 11 & 58080 & $1.9(0.95$ to 3.4$)$ \\
\hline Andes (4) & 14 & 52372 & $2.7(1.5$ to 4.5$)$ & 9 & 40520 & $2.2(1.0$ to 4.2$)$ \\
\hline Subandina (1) & 4 & 27950 & $1.4(0.4$ to 3.7$)$ & 2 & 17560 & $1.1(0.14$ to 4.1$)$ \\
\hline Brazil (22): & 251 & 303922 & $8.3(7.3$ to 9.4$)$ & 114 & 209834 & $5.4(4.5$ to 6.5$)$ \\
\hline Centro (1) & 1 & 3997 & $2.5(0.06$ to 13.9$)$ & 1 & 3854 & $2.6(0.07$ to 14.5$)$ \\
\hline Nordeste (4) & 76 & 90891 & $8.4(6.6$ to 10.5$)$ & 34 & 49501 & 6.9 (4.8 to 9.6$)$ \\
\hline Sudeste (11) & 144 & 88052 & $16.4^{\star}(13.8$ to 19.3$)$ & 70 & 68178 & $10.3(8$ to 12.9$)$ \\
\hline Sul (6) & 30 & 120982 & 2.5 (1.7 to 3.5$)$ & 9 & 88301 & $1.0(0.47$ to 1.9$)$ \\
\hline Chile (11): & 89 & 192401 & $4.6(3.7$ to 5.7$)$ & 43 & 102631 & $4.2(3.0$ to 5.6$)$ \\
\hline Lagos (1) & 7 & 34665 & $2.0(0.81$ to 4.2$)$ & 5 & 23229 & $2.2(0.70$ to 5.0$)$ \\
\hline Maule (4) & 19 & 91244 & 2.1 (1.3 to 3.3$)$ & 12 & 49915 & $2.4(1.2$ to 4.2$)$ \\
\hline Metropolitana (6) & 63 & 66492 & $9.5(7.3$ to 12.1$)$ & 26 & 29487 & $8.8(5.8$ to 12.9$)$ \\
\hline Colombia (15): & 53 & 152485 & $3.5(2.6$ to 4.6$)$ & 41 & 122437 & $3.3(2.4$ to 4.5$)$ \\
\hline Caribe (1) & 2 & 1411 & $14.2(1.7$ to 51.2$)$ & 1 & 1411 & $7.1(0.18$ to 39.5$)$ \\
\hline Sabana (12) & 40 & 83693 & $4.8(3.4$ to 6.5$)$ & 34 & 69115 & $4.9(3.4$ to 6.9$)$ \\
\hline Valle (2) & 11 & 67381 & $1.6(0.8$ to 2.9$)$ & 6 & 51911 & $1.2(0.4$ to 2.5$)$ \\
\hline Ecuador (11): & 23 & 81835 & 2.8 (1.8 to 4.2$)$ & 10 & 63085 & $1.6(0.76$ to 2.9$)$ \\
\hline Costa (4) & 2 & 19484 & $1.0(0.1$ to 3.7$)$ & 0 & 16666 & 0 (0 to 2.2$)$ \\
\hline Sierra (7) & 21 & 62351 & $3.4(2.1$ to 5.2$)$ & 10 & 46419 & 2.2 (1.0 to 3.9$)$ \\
\hline Paraguay (1): & 1 & 5237 & $1.9(0.05$ to 10.6$)$ & 0 & 1885 & $0(0$ to 19.6$)$ \\
\hline Asuncion (1) & 1 & 5237 & $1.9(0.05$ to 10.6$)$ & 0 & 1885 & 0 (0 to 19.6) \\
\hline Peru (1): & 6 & 19881 & 3.0 (1.1 to 6.6$)$ & 6 & 19881 & 3.0 (1.1 to 6.6$)$ \\
\hline Lima (1) & 6 & 19881 & 3.0 (1.1 to 6.6$)$ & 6 & 19881 & 3.0 (1.1 to 6.6$)$ \\
\hline Uruguay (2): & 0 & 9553 & 0 (0 to 3.9) & 0 & 9553 & 0 (0 to 3.9) \\
\hline Maldonado (1) & 0 & 1922 & 0 & 0 & 1922 & 0 \\
\hline Montevideo (1) & 0 & 7631 & 0 & 0 & 7631 & 0 \\
\hline Venezuela (4): & 16 & 84778 & 1.9 (1.1 to 3.1$)$ & 4 & 55986 & 0.71 (0.19 to 1.8$)$ \\
\hline Guyana (1) & 1 & 9868 & $1.0(0.03$ to 5.7$)$ & 1 & 9868 & $1.0(0.03$ to 5.7$)$ \\
\hline Occidente (1) & 13 & 54317 & $2.4(1.3$ to 4.1$)$ & 2 & 25525 & 0.78 (0.09 to 2.8$)$ \\
\hline Zulia (2) & 2 & 20593 & $1.0(0.12$ to 3.5$)$ & 1 & 20593 & 0.49 (0.01 to 2.7$)$ \\
\hline All countries (107) & 552 & 1247185 & $4.4^{\star}(4.1$ to 4.9$)$ & 268 & $881074 \dagger$ & $3.0(2.7$ to 3.4$)$ \\
\hline
\end{tabular}


Country, region (hospital ID)

Argentina, Buenos Aires (318)

Argentina, Buenos Aires (322)

Argentina, Buenos Aires (332)

Argentina, Centro (510)

Argentina, Cuyo (601)

Argentina, Cuyo (614)

Argentina, Nordeste (704)

Argentina, Nordeste (803)

Argentina, Pampa (413)

Argentina, Pampa (416)

Argentina, Pampa (418)

Bolivia, Andes (B01)

Bolivia, Andes (B07)

Bolivia, Andes (B10)

Brazil, Nordeste (A47)

Brazil, Nordeste (A48)

Brazil, Nordeste (A56)

Brazil, Nordeste (A63)

Brazil, Sudeste (A10)

Brazil, Sudeste (A33)

Brazil, Sudeste (A39)

Brazil, Sudeste (A60)

Brazil, Sudeste (A62)

Brazil, Sul (A04)

Brazil, Sul (A25)

Brazil, Sul (A50)

Brazil, Sul (A51)

Chile, Lagos (220)

Chile, Maule (219)

Chile, Maule (225)

Chile, Maule (227)

Chile, Metropolitana (201)

Chile, Metropolitana (217)

Colombia, Sabana (G11)

Colombia, Sabana (G12)

Colombia, Sabana (G13)

Colombia, Sabana (G16)

Colombia, Sabana (G20)

Colombia, Sabana (G22)

Colombia, Valle (G19)

Colombia, Valle (G25)

Ecuador, Costa (E04)

Ecuador, Costa (E08)

Ecuador, Sierra (E01)

Ecuador, Sierra (E09)

Ecuador, Sierra (E10)

Paraguay, Asuncion (D04)

Peru, Lima (C05)

Uruquay, Montevideo (110)

Venezuela, Guyana (F05)

Venezuela, Occidente (F02)

Venezuela, Zulia (F01)

Venezuela, Zulia (F07)

Overall birth prevalence
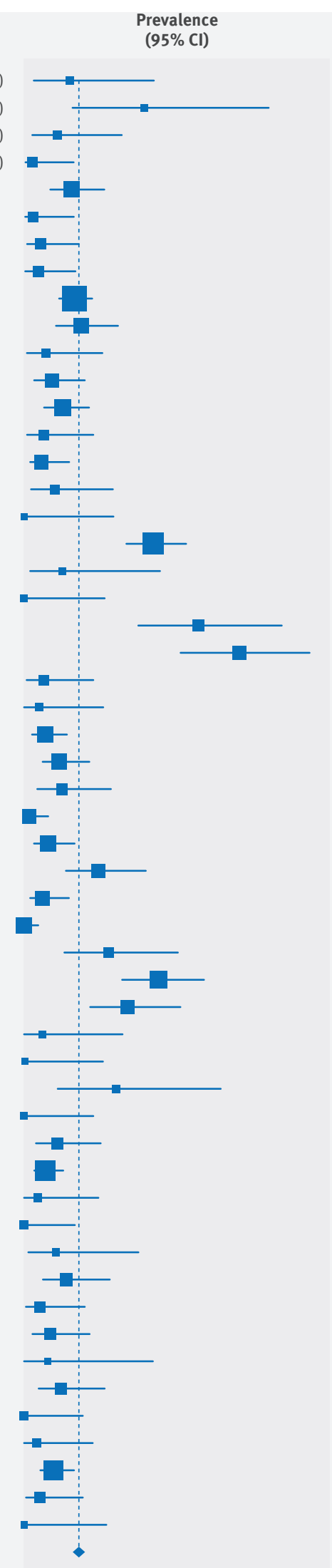

$\begin{array}{llllll}0 & 5 & 10 & 15 & 20 & 25\end{array}$

\section{Weight Prevalence \\ (\%) \\ (95\% Cl)}

0.72

0.63

0.97

1.19

2.94

1.18

1.40

1.50

7.78

2.81

1.00

2.30

3.44

1.11

2.45

1.06

0.44

5.89

0.57

0.49

1.53

2.24

1.11

0.75

3.17

3.28

1.41

2.48

3.04

2.17

2.40

3.00

1.27

3.58

2.36

0.60

0.50

0.71

0.56

1.62

5.10

0.80

0.77

0.67

1.80

1.30

1.66

0.46

1.74

0.67

0.86

4.76

1.33

0.48

100.00
3.7 (0.8 to 10.7)

2.7 (0.6 to 8.0 )

0.7 (0.0 to 4.1)

3.9 (2.1 to 6.6)

0.7 (0.0 to 4.1)

1.3 (0.2 to 4.5)

$1.2(0.1$ to 4.2$)$

4.1 (2.8 to 5.6 )

4.7 (2.6 to 7.7 )

1.8 (0.2 to 6.4$)$

2.3 (0.8 to 5.0 )

3.1 (1.6 to 5.3 )

$1.6(0.2$ to 5.7$)$

1.4 (0.4 to 3.7 )

2.5 (0.5 to 7.3$)$

0.0 (0.0 to 7.3$)$

10.6 (8.3 to 13.3$)$

3.1 (0.4 to 11.1$)$

0.0 (0.0 to 6.6)

14.3 (9.3 to 21.1 )

17.6 (12.8 to 23.5 )

$1.6(0.2$ to 6.5$)$

$1.2(0.0$ to 6.5$)$

1.7 (0.6 to 3.6)

2.9 (1.5 to 5.3$)$

3.1 (1.0 to 7.2 )

0.4 (0.0 to 2.0 )

$2.0(0.8$ to 4.2$)$

6.1 (3.4 to 10.0 )

1.5 (0.4 to 3.7)

0.0 (0.0 to 1.1$)$

6.9 (3.3 to 12.7$)$

11.0 (8.0 to 14.8$)$

8.5 (5.4 to 12.8 )

1.5 (0.0 to 8.1)

$0.0(0.0$ to 6.5$)$

7.5 (2.7 to 16.2$)$

0.0 (0.0 to 5.7)

2.7 (0.9 to 6.3)

1.7 (0.8 to 3.2)

1.1 (0.0 to 6.1)

0.0 (0.0 to 4.2)

2.6 (0.3 to 9.4)

3.4 (1.4 to 7.0 )

$1.3(0.2$ to 4.9$)$

2.1 (0.6 to 5.4$)$

$1.9(0.1$ to 10.6$)$

3.0 (1.1 to 6.6$)$

0.0 (0.0 to 4.8)

1.0 (0.0 to 5.7)

2.4 (1.3 to 4.1 )

1.3 (0.2 to 4.8$)$

0.0 (0.0 to 6.8)

4.4 (4.1 to 4.9)
9.8 (3.9 to 20.1 )

Fig 2 | Forest plot of hospital based prevalence per hospital (country, region), $2005-14$, showing only 55 hospitals with $\geq 5000$ births. Hospital codes are given in supplementary table. Hospital A05 not shown as off scale: hospital based prevalence $=72 / 10000(95 \% \mathrm{Cl} 56.1$ to $91.0 ; n=69$, births=9582)
Extrapolated to the 6.8 million births in South America, we estimate that the number of microcephaly cases being born per year before Zika was between 2058 (simple estimate) and 2465 (stratified estimate, substituting South American average prevalence for the two countries with zero cases in table 2).

\section{Clinical and phenotypic spectrum}

Table 1 shows the distribution of clinical classification (2005-14). Twenty three per cent or 1.0 per 10000 births were genetic syndromes, 5\% were embryopathies, $34 \%$ were polymalformed, $12 \%$ were microcephaly with associated neural conditions, and $26 \%$ were coded only as microcephaly; 230 cases (42\% of all cases) were neural only cases (table 1 ). The sex ratio was significantly skewed towards females (tables 1 and 3).

Fifty four per cent of microcephaly cases were low birth weight (<2500 g) (table 3); $27 \%$ of microcephaly cases had a birth weight lighter than 2 SD below the mean (-2 SD), including 7\% with a birth weight lighter than -3 SD (table 3). For the 2010-14 period cases, $45 \%$ of head circumferences were less than -3 SD and $24 \%$ were between -3 and -2 SD. On inspection of $41 / 58$ cases with head sizes larger than -2 SD, eight (19\%) had hydrocephaly, seven (17\%) had spina bifida, two (5\%) had lissencephaly, and seven (17\%) had other cerebral defects; other conditions (2 (1\%)) were mentioned in which brain size might not be reflected in head size, such as head deformity and loose/redundant skin over the head, and others were unexplained. Of the 126 cases with a head size smaller than -2 SD, 47 (37\%) also had a birth weight smaller than -2 SD. The equivalent figure for -3 SD was 82 cases, of which $10(12 \%)$ also had a birthweight smaller than $-3 \mathrm{SD}$.

Parental consanguinity was present in $2 \%(n=11)$ of all cases and $0.7 \%$ of controls (table 4 ). Four of the consanguineous cases had been diagnosed as having genetic syndromes (category A), but consanguinity was also present in seven isolated (category D) cases with no diagnosed genetic syndrome, of which five were first cousins. The association between consanguinity and neural only microcephaly was strong (odds ratio 3.1, 95\% confidence interval 1.4 to 7.0) (table 4).

STORCH embryopathies were diagnosed in $3.8 \%$ of total cases (table 1), with an odds ratio of 4.4 (2.3 to 8.4) (table 4). Of the 21 STORCH microcephaly cases, 15 were neural only cases ( $7 \%$ of all neural only cases) and six had other congenital anomalies (table 1).

The polymalformed cases included 13 with microcephaly and arthrogryposis, all of which also had other malformations of non-neural origin. There were no cases of microcephaly and arthrogryposis that did not also have non-neural origin anomalies.

\section{Sociodemographic risk factors}

For all cases and neural only cases, we found no association with older maternal age or low maternal education (table 4). 


\begin{tabular}{|c|c|c|}
\hline Characteristic & $\begin{array}{l}\text { All microcephaly } \\
\text { cases }(n=552)\end{array}$ & $\begin{array}{l}\text { Neural only } \\
\text { cases }(n=230)\end{array}$ \\
\hline Live born & $525(95.1)$ & $229(>99)$ \\
\hline Stillborn & $25(4.5)$ & $1(0.4)$ \\
\hline All perinatal deaths & $159(28.8)$ & $17(7)$ \\
\hline Male & $227(41.1)$ & $92(40)$ \\
\hline Female & $315(57.1)$ & $138(60)$ \\
\hline Intersex & $8(1.4)$ & 0 \\
\hline Twin & $14(2.5)$ & $8(3)$ \\
\hline Prenatally diagnosed & $175(31.7)$ & $51(22)$ \\
\hline Preterm (<37 weeks) & $195(35.3)$ & $51(22)$ \\
\hline Term not specified & $32(5.8)$ & $17(7)$ \\
\hline Low birth weight $(<2500 \mathrm{~g})$ & $296(53.6)$ & $94(41)$ \\
\hline Birth weight z score not calculated & $46(8.3)$ & $29(13)$ \\
\hline Birth weight $<-2$ SD & $134 / 506(26.5)$ & 40/201 (20) \\
\hline Birth weight $<-3$ SD & $33 / 506(6.5)$ & $7 / 201(3)$ \\
\hline \multicolumn{3}{|l|}{ 2010-14 only } \\
\hline All data: & $235(42.6)$ & $95(41)$ \\
\hline HC z score not calculated $t$ & $51 / 235(22)$ & $8 / 95(8)$ \\
\hline $\mathrm{HC}<-3 \mathrm{SD}$ & $82 / 184(45)$ & $38 / 87(44)$ \\
\hline$-2 \mathrm{SD} \leq \mathrm{HC} \geq-3 \mathrm{SD}$ & 44/184 (24) & $27 / 87(31)$ \\
\hline$-1 \mathrm{SD} \leq \mathrm{HC}>-2 \mathrm{SD}$ & $37 / 184(20)$ & $18 / 87(21)$ \\
\hline $\mathrm{HC}>-1 \mathrm{SD}$ & $21 / 184(11)$ & $4 / 87(5)$ \\
\hline Preterm: & $55 / 184(30)$ & $15 / 87(17)$ \\
\hline $\mathrm{HC}<-3 \mathrm{SD}$ & $21 / 55(38)$ & $8 / 15(53)$ \\
\hline$-2 \mathrm{SD} \leq \mathrm{HC} \geq-3 \mathrm{SD}$ & $8 / 55(15)$ & $2 / 15(13)$ \\
\hline$-1 S D \leq H C>-2 S D$ & $14 / 55(25)$ & $4 / 15(27)$ \\
\hline$H C>-1 S D$ & $12 / 55(22)$ & $1 / 15(7)$ \\
\hline Term: & $129 / 184(70)$ & $72 / 87(83)$ \\
\hline $\mathrm{HC}<-3 \mathrm{SD}$ & $61 / 129(47)$ & $30 / 72(42)$ \\
\hline$-2 \mathrm{SD} \leq \mathrm{HC} \geq-3 \mathrm{SD}$ & $36 / 129(28)$ & $25 / 72(35)$ \\
\hline$-1 \mathrm{SD} \leq \mathrm{HC}>-2 \mathrm{SD}$ & $23 / 129(18)$ & $14 / 72(20)$ \\
\hline $\mathrm{HC}>-1 \mathrm{SD}$ & 9/129(7) & $3 / 72(4)$ \\
\hline
\end{tabular}

*Two cases were unspecified as to whether live born or stillborn and for sex.

tz score not calculated as sex not specified (2), intersex (4), gestational age not specified (1), gestational age outside Intergrowth range (24-42 weeks+6 days) (8), or head circumference not specified (43).

\section{Discussion}

Before the Zika epidemic, the average hospital based prevalence of microcephaly recorded by ECLAMC in South America for the 2005-14 period was 4.4 per 10000 births, and the estimated population based prevalence was 3.0 per 10000 . Prevalence varied considerably by country, region, and hospital. As selective referral of prenatally diagnosed cases of congenital anomaly or high risk pregnancies to tertiary hospitals may occur, the prevalence in single hospitals may be inflated compared with the population as a whole. We estimate the average population based prevalence to be $31 \%$ less than the hospital based prevalence and recommend that Zika related surveillance takes hospital selection into account and provides population based prevalence. However, we found that hospital selection explained little of the geographical variation in prevalence of diagnosed cases-substantial geographical variation remained in population based prevalence. On the basis of this prevalence of 3.0 per 10000 , we estimate that 2000 to 2500 babies were being diagnosed as having microcephaly each year before the Zika epidemic, among the nearly 7 million annual births in South America.

\section{Comparison with other studies}

Previous estimates of the prevalence of microcephaly in South America and elsewhere have been within a similar range. ECLAMC data showed an average hospital based prevalence of 3.7/10000 for 19822008, ranging from 2.1 in Venezuela to 5.1 in Brazil and 5.5 in Chile. ${ }^{37}$ Other studies in South America that overlap to a small extent with ECLAMC data reported a population based prevalence of $3.1 / 10000$ in the region of Risaralda, Colombia, in 2010-13 and a hospital based prevalence of 2.4/10000 in Argentina in 2010-14. ${ }^{38} 39$ In Europe in 2003-12, a population based prevalence of 1.5/10000, excluding 23\% with genetic syndromes, was recorded, ${ }^{31}$ and a hospital based prevalence of 2.3/10000 was reported in India from 1963 to $1995 .^{40}$ The pooled prevalence of microcephaly among the United States population based surveillance systems was higher at 8.7 per 10000 from 2009 to 2013. ${ }^{32}$ Both European and US surveillance systems documented considerable geographical variation, which was due at least in part to diagnostic variability.

\section{Implications for diagnosis of microcephaly}

The ECLAMC surveillance data, like data from other surveillance systems, ${ }^{31}{ }^{32}$ records diagnoses made by clinicians for clinical (not research) purposes, which are only to a limited extent subject to standardisation by belonging to a surveillance network. In our data, about half of cases had a head size larger than -3 SD (according to the Intergrowth curve), including some larger than -2 SD in whom other signs indicated an abnormally small brain. This is despite the ECLAMC recommendation to use a threshold of $-3 \mathrm{SD}$. Some of this discrepancy may relate to differences between the growth charts used (Intergrowth charts were not widely used in this period) and whether they explicitly show the $-3 \mathrm{SD}$ threshold measurements. Most readily available charts, including Intergrowth, showed only the third centile during this period, 35 41-43 the third centile being equivalent to the lowest 3\% of measurements of the reference population compared with $2.3 \%$ for -2 SD and $0.13 \%$ for -3 SD in a normal distribution (https://www.zscorecalculator.com/). It also follows that use of other charts might have meant that clinicians missed cases that would be microcephalic by the Intergrowth chart. A US analysis of surveillance data found that $42 \%$ of microcephaly cases had head circumference larger than the 10th centile (the lowest $10 \%$, equivalent to -1.3 SD) by the Intergrowth curve, an even greater proportion of large head circumferences than we found in South America. $^{32}$

Our data, the literature, 431324546 and discussions with paediatricians suggest that clinical judgment goes beyond a simple metric microcephaly. Paediatricians do (and should) use other signs as well as head circumference at birth to determine which baby has a small brain and whether this is likely to be associated with brain pathology and poor neurodevelopmental outcome. Head circumference is only a screening 


\begin{tabular}{|c|c|c|c|c|c|c|}
\hline \multirow[b]{2}{*}{ Exposure } & \multicolumn{3}{|c|}{ All microcephaly cases } & \multicolumn{3}{|c|}{ Neural only microcephaly } \\
\hline & $\begin{array}{l}\text { Cases } \\
(n=546)^{*}\end{array}$ & $\begin{array}{l}\text { Controls } \\
(n=2176)\end{array}$ & $\begin{array}{l}\text { Adjusted odds } \\
\text { ratio }(95 \% \mathrm{Cl})\end{array}$ & $\begin{array}{l}\text { Cases } \\
(n=230)\end{array}$ & $\begin{array}{l}\text { Controls } \\
(n=917)\end{array}$ & $\begin{array}{l}\text { Adjusted odds } \\
\text { ratio }(95 \% \mathrm{Cl})\end{array}$ \\
\hline \multicolumn{7}{|l|}{ Maternal age: } \\
\hline$<20$ years & $104(19.0)$ & $444(20.4)$ & $0.81(0.62$ to 1.0$)$ & $49(21)$ & $209(22.8)$ & $0.77(0.53$ to 1.1$)$ \\
\hline $20-34$ years & $360(65.9)$ & $1263(58.0)$ & 1.0 & $156(68)$ & $547(59.7)$ & 1.0 \\
\hline$\geq 35$ years & $82(15.0)$ & 241 (11.1) & $1.2(0.88$ to 1.6$)$ & $25(11)$ & $97(10.6)$ & $0.84(0.51$ to 1.4$)$ \\
\hline Not specified & 0 & $228(10.5)$ & - & 0 & $64(7.0)$ & - \\
\hline \multicolumn{7}{|c|}{ Maternal education: } \\
\hline$<6$ years & $111(20.3)$ & $345(15.9)$ & $1.2(0.92$ to 1.6$)$ & $37(16)$ & $147(16.0)$ & $1.0(0.64$ to 1.5$)$ \\
\hline $6-12$ years & $358(65.6)$ & $1364(62.7)$ & 1.0 & $161(70)$ & $597(65.1)$ & 1.0 \\
\hline$\geq 13$ years & $55(10.1)$ & $186(8.5)$ & $1.1(0.77$ to 1.5$)$ & $25(11)$ & $91(9.9)$ & $1.0(0.59$ to 1.6$)$ \\
\hline Not specified & $22(4.0)$ & $281(12.9)$ & - & $7(3)$ & $82(8.9)$ & - \\
\hline \multicolumn{7}{|l|}{ Consanguinity: } \\
\hline Yes & $11(2.0)$ & $15(0.7)$ & 3.1 (1.4 to 7.0$)$ & $7(3)$ & $10(1.1)$ & 3.1 (1.1 to 8.9$)$ \\
\hline No & $535(98.0)$ & $1865(85.7)$ & 1.0 & $216(94)$ & $818(89.2)$ & 1.0 \\
\hline Not specified & 0 & $296(13.6)$ & - & $7(3)$ & $89(9.7)$ & - \\
\hline \multicolumn{7}{|l|}{ STORCH: } \\
\hline Yes & $21(3.8)$ & $21(1.0)$ & $4.4(2.3$ to 8.3$)$ & $15(7)$ & $15(1.6)$ & $6.3(2.6$ to 15.1$)$ \\
\hline No & $525(96.2)$ & $2155(99.0)$ & 1.0 & $215(93)$ & $902(98.4)$ & 1.0 \\
\hline Not specified & 0 & 0 & - & 0 & 0 & - \\
\hline \multicolumn{7}{|l|}{ Diabetes: } \\
\hline Yes & $13(2.4)$ & $52(2.4)$ & $1.0(0.53$ to 1.9$)$ & $5(2)$ & $5(0.5)$ & $1.0(0.38$ to 2.9$)$ \\
\hline No & $533(97.6)$ & $2124(97.6)$ & 1.0 & $225(98)$ & $912(99.5)$ & 1.0 \\
\hline Not specified & 0 & 0 & - & 0 & 0 & - \\
\hline \multicolumn{7}{|l|}{ Influenza: } \\
\hline Yes & $26(4.8)$ & $57(2.6)$ & 1.9 (1.1 to 3.3$)$ & $12(5)$ & $12(1.3)$ & 2.7 (1.8 to 6.4$)$ \\
\hline No & $520(95.2)$ & $2119(97.4)$ & 1.0 & $218(95)$ & $905(98.7)$ & 1.0 \\
\hline Not specified & 0 & 0 & - & 0 & 0 & - \\
\hline
\end{tabular}

tool, but it may have assumed a status as a sole metric diagnostic arbiter in textbook definitions. Other signs that improve the predictive value may include slowing growth rate of the head in utero and postnatally, presence of associated major or minor malformations (59\% of our larger head size cases had neural anomalies that suggested small brain size) or abnormal facies suggesting teratogenic factors, exposure to known risk factors (of which Zika may become one), proportionality of head size to body size,${ }^{47}$ parental head size, brain imaging results, ${ }^{14} 15$ 48-50 52 and any abnormalities of head shape that invalidate judgments made about occipitofrontal head circumference such as head moulding or water loss. ${ }^{53-55}$

Some under-ascertainment of microcephaly in ECLAMC and other surveillance systems is also possible. When the underlying or an associated pathology is known and diagnosed-for example, a specific syndrome or specific brain malformationmicrocephaly may not always be specified as a supplementary diagnosis.

The WHO has recommended in response to the Zika epidemic that microcephaly should be defined as head circumference below $-2 \mathrm{SD},{ }^{51}$ rather than $-3 \mathrm{SD}$ as used by congenital anomaly surveillance systems, ${ }^{3132}$ particularly as not all Zika affected babies have heads smaller than $-3 \mathrm{SD}^{142150}$ As a definition of $-2 \mathrm{SD}$ on its own has the disadvantage of low specificity, ${ }^{50}$ and unnecessary anxiety, giving many babies with normal brains a microcephaly diagnosis, ${ }^{2246}$ and leading to a huge potential increase in recorded microcephaly prevalence compared with previous levels, both the Brazilian microcephaly monitoring and the WHO surveillance manual have recommended that a diagnosis of microcephaly should be confirmed at this level for congenital Zika surveillance only if other evidence of structural abnormalities exists. ${ }^{33}{ }^{51}$ The implementation of this definition may lead to a certain amount of standardisation in future but leave several areas of potential variability as discussed above. What is clear is that purely "metric microcephaly" is not a viable definition of a clinical entity, even when restricted to $-3 \mathrm{SD}$, and also that an alert such as Zika has the potential to lead to large artefactual increases in the prevalence of diagnosed microcephaly. Microcephaly surveillance should move beyond measurement based definition to a pathology based definition.

\section{Potential explanations and implications}

In the period 2005-14 before Zika, the highest microcephaly prevalences in our data were already recorded in Brazil, especially southeast and northeast Brazil, where later (from 2015 on) the Zika epidemic and microcephaly surge began, but a high prevalence was also observed in metropolitan Chile. We have no explanation for this or more generally for the geographic variation observed-a vulnerability to or higher background frequency of teratogenic exposures, or diagnostic factors as discussed above, or both could be hypothesised. 
The range of abnormalities associated with congenital Zika syndrome are still being defined. ${ }^{19-28}$ Although initially the recognition of this syndrome drove a widening of the microcephaly definition, it is now recognised that microcephaly is only one of a range of neural abnormalities. We found $2.4 \%$ (13/552) of cases of microcephaly with arthrogryposis, one of the findings relating to Zika, ${ }^{17} 18$ but these were all polymalformed cases that also had other non-neural malformations. At least 34 genetic syndromes present with congenital microcephaly plus arthrogryposis. ${ }^{56}$ Intrauterine growth retardation has been a common Zika related finding, ${ }^{1315}$ including in animal models. ${ }^{5758}$ We found proportionate microcephaly to account for $37 \%$ of babies with head size less than -2 SD, but for those with head size more than -3 SD it was uncommon for birth weight to be proportionately reduced. Development of the congenital Zika syndrome definition will need to consider carefully whether to distinguish proportionate growth retardation with normally formed brain from microcephaly with evidence of abnormal brain structure, including consideration of prognosis in terms of neurodevelopmental outcome, which may come from the cohort studies now in progress.

Twenty three per cent of our cases had a diagnosed genetic syndrome, a prevalence of 1 per 10000 , similar to the $23 \%$ of genetic cases reported by EUROCAT and $23 \%$ reported in the US, ${ }^{31}{ }^{32}$ and it is important that differential diagnosis is maintained during epidemic periods. Autosomal recessive types of microcephaly, well recognised in the microcephaly literature, ${ }^{59}$ for which consanguineous parents would be at higher risk, are more difficult to identify at birth as suggested by our very high odds ratio for parental consanguinity among neural only cases, of which few had been diagnosed as having syndromes. As new genetic diagnostic methods become more widely available, the proportion of genetic syndromes is likely to rise in future.

Although Zika is of great relative importance during an epidemic, owing to high numbers of exposed nonimmune women, the strong and known associations we found with other infections are of continuing importance. Current estimates of the rate of affected babies after Zika infection in early pregnancy are in the order of $1-13 \%,{ }^{26061}$ but infections such as rubella are more highly teratogenic (with up to $100 \%$ birth defects when exposure occurred before the 11 th week or $35 \%$ of those infected between the 13 th and 16 th weeks) but not as specific to neural anomalies. ${ }^{62} \mathrm{We}$ found in these pre-Zika data that $4 \%$ of microcephaly cases (or $7 \%$ of neural only cases) were associated with STORCH infections, in some cases more than one infection. A Colombian surveillance study reported that $21 \%$ of microcephaly cases tested had evidence of STORCH infections. ${ }^{63}$ The STORCH infections in $1.5 \%$ of our non-malformed controls, some of whom may have had later neurodevelopmental problems, suggest a significant population level of maternal infection during pregnancy, even though this is likely to be an underestimate owing to incomplete screening. We also found a significant association with reported influenza, which has not previously been found in the literature, ${ }^{64}$ that may also indicate fever relating to other infectious diseases being interpreted as influenza. Zika may be a useful "wake-up call" to the effect of infections during pregnancy. Each STORCH infection is estimated to be associated with between 100000 and more than a million cases of congenital infection globally each year. ${ }^{56567}$

\section{Strengths and limitations of study}

A strength of the ECLAMC surveillance system is that it uses a common protocol in all countries. However, hospitals receive no funding for their participation and are not able to follow up cases beyond discharge from the maternity unit. This means that some brain imaging and genetic syndrome diagnoses for microcephaly cases may be missing, and some of the polymalformed or isolated cases classified here may have later been given syndrome diagnoses. Diagnostic data are collected within the healthcare possibilities of each hospital, in a "real world" rather than research context. This is common to surveillance systems worldwide, $^{31} 32$ which use standardised reporting systems for healthcare data that may arise from nonstandardised clinical practice. We found that data were missing for some variables, which indicates the need for improved reporting in ECLAMC. Mothers may not accurately or completely recall information about their exposures when interviewed. Our description of head circumference of microcephaly cases was limited to 2010-14 and may not be representative of the earlier period (2005-09).

Whereas hospital based surveillance has the advantage of ensuring high data quality coming from selected participating hospitals, a strength of the ECLAMC system, selective referral to tertiary or specialist hospitals is problematic for the estimation of population based prevalence. As there are often multiple hospitals within municipalities, and it was not possible to correct for within municipality selection, we could not give fully population based prevalence estimates, but we believe our population based estimates to be an improvement over the hospital based estimates for public health surveillance. Our extrapolation to the entire population of South America is approximate only. All South American countries, except Guyana, Suriname, and French Guiana, were represented in our data.

\section{Conclusions}

We have established a baseline for the prevalence of diagnosed microcephaly before the Zika epidemic with which the prevalence during and after the Zika epidemic can be compared, with strong caveats due to the problems of definition. We have also shown that, even in non-Zika times, the potential effects of infectious and non-infectious causes of abnormal brain development should not be ignored. What may set the Zika epidemic apart from other endemic infections are 
the high exposure rate in the population as it sweeps through non-immune populations and its specificity to neural anomalies.

We thank the ECLAMC members, especially the 107 physicians who collected all the data and the ECLAMC staff including Mariana Piola and Alejandra Mariona.

Contributors: IMO, JSLC, HD, and EEC conceived the research question. HD wrote the draft of the manuscript with furthe modifications from all authors. JSLP did the statistical analysis, and HD and FAP advised on all statistical aspects. Clinical analysis was done by IMO. IMO, HD, JSLC, DM, FAP, MGD, FMC, and EEC contributed to the interpretation of the results and critical revision of the manuscript for important intellectual content. All authors had full access to all of the data (including statistical reports and tables) in the study and can take responsibility for the integrity of the data and the accuracy of the data analysis. IMO and EEC are the guarantors.

Funding: This research was funded by the MRC Rapid Response Initiative ZK/16-075 Zika: Establishment of enhanced birth defect surveillance in South America, supported jointly by MRC, Newton Fund, and Wellcome Trust, and was also partially supported by MCTIC/ FNDCT-CNPq/MEC-CAPES/MS-Decit/No 14/2016 - Prevenção e Combate ao vírus Zika, European Union Horizon 2020 ZikaPLAN grant agreement No 734584 and Bolsista CAPES/BRASIL. Funding sources had no role in the study design, data acquisition, or analyses or in the decision to submit the article for publication.

Competing interests: All authors have completed the ICMJE uniform disclosure form at www.icmje.org/coi_disclosure.pdf and declare: no support from any organisation for the submitted work; no financial relationships with any organisations that might have an interest in the submitted work in the previous three years; no other relationships or activities that could appear to have influenced the submitted work.

Ethical approval: This study was approved by the ethical committee in Rio de Janeiro, Brazil (CAAE: 59488716.1.1001.5269).

Data sharing: The data used in this study belong to the individual hospitals. Data are available on request from the corresponding author, who will ask the individual hospitals' permission to use the data.

Transparency: The lead author affirms that the manuscript is an honest, accurate, and transparent account of the study being reported; that no important aspects of the study have been omitted; and that any discrepancies from the study as planned (and, if relevant, registered) have been explained

This is an Open Access article distributed in accordance with the Creative Commons Attribution Non Commercial (CC BY-NC 4.0) license, which permits others to distribute, remix, adapt, build upon this work non-commercially, and license their derivative works on different terms, provided the original work is properly cited and the use is non-commercial. See: http://creativecommons.org/licenses/ by-nc/4.0/.

1 Ministério da Saúde do Brasil. Ministério da Saúde investiga aumento de casos de microcefalia em Pernambuco. 2015. http:// portalsaude.saude.gov.br/index.php/cidadao/principal/agenciasaude/20629-ministerio-da-saude-investiga-aumento-de-casosde-microcefalia-em-pernambuco.

2 Cauchemez S, Besnard M, Bompard P, et al. Association between Zika virus and microcephaly in French Polynesia, 2013-15: a retrospective study. Lancet 2016;387:2125-32. doi:10.1016/ S0140-6736(16)00651-6

3 World Health Organization. WHO statement on the first meeting of the International Health Regulations (2005) (IHR 2005) Emergency Committee on Zika virus and observed increase in neurological disorders and neonatal malformations. 2016. http://www.who.int/ mediacentre/news/statements/2016/1st-emergency-committeezika/en/.

4 Ashwal S, Michelson D, Plawner L, Dobyns WBQuality Standards Subcommittee of the American Academy of Neurology and the Practice Committee of the Child Neurology Society. Practice parameter: Evaluation of the child with microcephaly (an evidencebased review): Report of the quality standards subcommittee of the American academy of neurology and the practice committee of the child neurology society. Neurology 2009;73:887-97. doi:10.1212/WNL.0b013e3181b783f7

5 Lambert N, Strebel P, Orenstein W, Icenogle J, Poland GA. Rubella. Lancet 2015;385:2297-307. doi:10.1016/S01406736(14)60539-0

6 Boppana SB, Ross SA, Fowler KB. Congenital cytomegalovirus infection: clinical outcome. Clin Infect Dis 2013;57(Suppl 4): S178-81. doi:10.1093/cid/cit629
7 McAuley JB. Congenital Toxoplasmosis. J Pediatric Infect Dis Soc 2014;3(Suppl 1):S30-5. doi:10.1093/jpids/piu077

8 Fuchs F, Michaux K, Rousseau C, Ovetchkine P, Audibert F. Syphilis Infection: An Uncommon Etiology of Infectious Nonimmune Fetal Hydrops with Anemia. Fetal Diagn Ther 2016;39:74-7. doi:10.1159/000364804

9 Bale JFJr, Murph JR. Congenital infections and the nervous system. Pediatr Clin North Am 1992;39:669-90. doi:10.1016/S00313955(16)38370-5

10 Centers for Disease Control and Prevention. CDC concludes zika causes microcephaly and other birth defects. 2016. https://www.cdc. gov/media/releases/2016/s0413-zika-microcephaly.html.

11 Rasmussen SA, Jamieson DJ, Honein MA, Petersen LR. Zika Virus and Birth Defects--Reviewing the Evidence for Causality. N Engl J Med 2016;374:1981-7. doi:10.1056/NEJMsr1604338

12 Vouga M, Baud D. Imaging of congenital Zika virus infection: the route to identification of prognostic factors. Prenat Diagn 2016;36:799-811. doi:10.1002/pd.4880

13 Brasil P, Pereira JPJr, Moreira ME, et al. Zika Virus Infection in Pregnant Women in Rio de Janeiro. N Engl J Med 2016;375:2321-34. doi:10.1056/NEJMoa1602412

14 de Araújo TVB, Rodrigues LC de Alencar Ximenes RA, et al. investigators from the Microcephaly Epidemic Research Group. Brazilian Ministry of Health. Pan American Health Organization. Instituto de Medicina Integral Professor Fernando FigueiraState Health Department of Pernambuco. Association between Zika virus infection and microcephaly in Brazil, January to May, 2016: preliminary report of a case-control study. Lancet Infect Dis 2016:16:1356-63 doi:10.1016/S1473-3099(16)30318-8

15 van der Linden V, Pessoa A, Dobyns W, et al. Description of 13 Infants Born During October 2015-January 2016 With Congenital Zika Virus Infection Without Microcephaly at Birth - Brazil. MMWR Morb Mortal Wkly Rep 2016;65:1343-8. doi:10.15585/mmwr. mm6547e2

16 de Paula Freitas B, de Oliveira Dias JR, Prazeres J, et al. Ocular Findings in Infants With Microcephaly Associated With Presumed Zika Virus Congenital Infection in Salvador, Brazil. JAMA Ophthalmol 2016;134:529. doi:10.1001/ jamaophthalmol.2016.0267

17 van der Linden V, Filho ELR, Lins OG, et al. Congenital Zika syndrome with arthrogryposis: retrospective case series study. BM/ 2016:354:i3899 doi:10.1136/bmj.i3899

18 Martines RB, Bhatnagar J, de Oliveira Ramos AM, et al. Pathology of congenital Zika syndrome in Brazil: a case series. Lancet 2016;388:898-904. doi:10.1016/S0140-6736(16) 30883-2

19 Melo AS, Aguiar RS, Amorim MMR, et al. Congenital Zika Virus Infection: Beyond Neonatal Microcephaly. JAMA Neurol 2016:73:1407-16. doi:10.1001/jamaneurol.2016.3720

20 Miranda-Filho DdeB, Martelli CM, Ximenes RA, et al. Initial Description of the Presumed Congenital Zika Syndrome. Am Public Health 2016:106:598-600 doi:10.2105/AJPH.2016. 303115

21 França GVA, Schuler-Faccini L, Oliveira WK, et al. Congenital Zika virus syndrome in Brazil: a case series of the first 1501 livebirth with complete investigation. Lancet 2016;388:891-7. doi:10.1016 S0140-6736(16)30902-3

22 Moore CA Staples JE, Dobyns WB, et al. Characterizing the Pattern of Anomalies in Congenital Zika Syndrome for Pediatric Clinicians. JAMA Pediatr 2017;171:288-95. doi:10.1001/jamapediatrics.2016.3982

23 de Fatima Vasco Aragao M, van der Linden V, Brainer-Lima AM, et al. Clinical features and neuroimaging (CT and MRI) findings in presumed Zika virus related congenital infection and microcephaly: retrospective case series study. BMJ 2016;353:11901. doi:10.1136/ bmj.i1901

24 Verçosa I, Carneiro P, Verçosa R, et al. The visual system in infants with microcephaly related to presumed congenital Zika syndrome. IAAPOS 2017;21:300-304.e1. doi:10.1016/j.jaapos.2017.05.024

25 Leal MC, van der Linden V, Bezerra TP, et al. Characteristics of Dysphagia in Infants with Microcephaly Caused by Congenital Zika Virus Infection, Brazil, 2015. Emerg Infect Dis 2017;23:1253-9. doi:10.3201/eid2308.170354

26 Lucey D, Cummins H, Sholts S. Congenital Zika Syndrome in 2017. JAMA 2017;317:1368-9. doi:10.1001/jama.2017.1553

27 Ventura LO, Ventura CV, Lawrence L, et al. Visual impairment in children with congenital Zika syndrome. J AAPOS 2017;21:295-299. e2. doi:10.1016/j.jaapos.2017.04.003

28 Del Campo M, Feitosa IML, Ribeiro EM, et al. Zika Embryopathy Task Force-Brazilian Society of Medical Genetics ZETF-SBGM. The phenotypic spectrum of congenital Zika syndrome. Am J Med Genet A 2017:173:841-57. doi:10.1002/ajmg.a.38170

29 Reef SE, Plotkin S, Cordero JF, et al. Preparing for elimination of congenital Rubella syndrome (CRS): summary of a workshop on CRS elimination in the United States. Clin Infect Dis 2000;31:85-95. doi:10.1086/313928 
30 Soares de Oliveira-Szejnfeld P, Levine D, Melo AS de O, et al. Congenital Brain Abnormalities and Zika Virus: What the Radiologist Can Expect to See Prenatally and Postnatally. Radiology 2016;281:203-18. doi:10.1148/radiol.2016161584

31 Morris JK, Rankin J, Garne E, et al. Prevalence of microcephaly in Europe: population based study. BMJ 2016;354:i4721. doi:10.1136/bmj.i4721

32 Cragan JD, Isenburg JL, Parker SE, et al. National Birth Defects Prevention Network. Population-based microcephaly surveillance in the United States, 2009 to 2013: An analysis of potential sources of variation. Birth Defects Res A Clin Mol Teratol 2016;106:972-82. doi:10.1002/bdra. 23587

33 Ministério da Saúde do Brasil. Brasil adota recomendação da OMS e reduz medida para microcefalia. 2016. http:// portalsaude.saude.gov.br/index.php/cidadao/principal/agenciasaude/22553-brasil-adota-recomendacao-da-oms-e-reduzmedida-para-microcefalia.

34 Castilla EE, Orioli IM. ECLAMC: the Latin-American collaborative study of congenital malformations. Community Genet 2004;7:76-94.

35 Villar J, Cheikh Ismail L, Victora CG, et al. International Fetal and Newborn Growth Consortium for the 21st Century (INTERGROWTH-21st). International standards for newborn weight, length, and head circumference by gestational age and sex: the Newborn Cross-Sectional Study of the INTERGROWTH21 st Project. Lancet 2014;384:857-68. doi:10.1016/S01406736(14)60932-6

36 Mason CA, Kirby RS, Sever LE, Langlois PH. Prevalence is the preferred measure of frequency of birth defects. Birth Defects Res $A$ Clin Mol Teratol 2005;73:690-2. doi:10.1002/bdra.20211

37 Nazer HJ, Cifuentes OL. [Congenital malformations in Latin America in the period 1995-2008]. Rev Med Chil 2011;139:72-8

38 Porras-Hurtado GL, León-Castañeda OM, Molano-Hurtado J, Quiceno SL, Pachajoa H, Montoya JJ. [Prevalence of birth defects in Risaralda, 2010-2013]. Biomedica 2016;36:556-63. doi:10.7705/ biomedica.v36i4.2771

39 Groisman B, Bidondo MP, Liascovich R, et al. Microcefalia En Argentina Según Datos De La Red Nacional De Anomalías Congénitas. Rev Argentina Salud Pública 2016;7:39-42.

40 Bhide P, Kar A. Birth prevalence of microcephaly in India. Bull World Health Organ 2016;23.

41 World Health Organization Multicentre Growth Reference Study Group. WHO child growth standards: length/height-for-age, weightfor-age, weight-for-length, weight-for-height and body mass index-forage: methods and development. WHO, 2006.

42 Villar J, Giuliani F, Fenton TR, Ohuma EO, Ismail LC, Kennedy SHINTERGROWTH-21st Consortium. INTERGROWTH-21st very preterm size at birth reference charts. Lancet 2016;387:844-5. doi:10.1016/S0140-6736(16)00384-6

43 Fenton TR, Kim JH. A systematic review and meta-analysis to revise the Fenton growth chart for preterm infants. $B M C$ Pediatr 2013;13:59. doi:10.1186/1471-2431-13-59

45 Leviton A, Holmes LB, Allred EN, Vargas J. Methodologic issues in epidemiologic studies of congenital microcephaly. Early Hum Dev 2002;69:91-105. doi:10.1016/S0378-3782(02)00065-8

46 Dolk H. The predictive value of microcephaly during the first year of life for mental retardation at seven years. Dev Med Child Neurol 1991;33:974-83. doi:10.1111/j.1469-8749.1991. tb14813.x

47 Hofman MA. A biometric analysis of brain size in micrencephalics. J Neurol 1984:231:87-93. doi:10.1007/BF00313723

48 Brasil P, Nielsen-Saines K. More pieces to the microcephaly-Zika virus puzzle in Brazil. Lancet Infect Dis 2016;16:1307-9. doi:10.1016/ S1473-3099(16)30372-3
49 Woods CG, Parker A. Investigating microcephaly. Arch Dis Child 2013;98:707-13. doi:10.1136/archdischild-2012-302882

50 Victora CG, Schuler-Faccini L, Matijasevich A, Ribeiro E, Pessoa A, Barros FC. Microcephaly in Brazil: how to interpret reported numbers?Lancet 2016;387:621-4. doi:10.1016/S01406736(16)00273-7

51 World Health Organization. Screening, assessment and management of neonates and infants with complications associated with Zika virus exposure in utero: rapid advice guideline. WHO, 2016.

52 Hanzlik E, Gigante J. Microcephaly. Children (Basel) 2017;4:47. doi:10.3390/children4060047

53 Souza SW, Ross J, Milner RD. Alterations in head shape of newborn infants after caesarean section or vaginal delivery. Arch Dis Child 1976;51:624-7. doi:10.1136/adc.51.8.624

54 Rutter N, Hinchliffe W, Cartlidge PH. Do preterm infants always have flattened heads?Arch Dis Child 1993;68:606-7. doi:10.1136/ adc.68.5_Spec_No.606

55 Williams J, Hirsch NJ, Corbet AJS, Rudolph AJ, et al. Postnatal head shrinkage in small infants. Pediatrics 1977;59:619-22

56 OMIM. Online mendelian inheritance in man. 2017. https://www. omim.org/.

57 Cugola FR, Fernandes IR, Russo FB. The Brazilian Zika virus strain causes birth defects in experimental models. Nature 2016;534: 267-71.

58 Yockey LJ, Varela L, Rakib T, et al. Vaginal Exposure to Zika Virus during Pregnancy Leads to Fetal Brain Infection. Cell 2016;166:1247-1256.e4. doi:10.1016/j.cell.2016.08.004

59 Woods CG Bond J, Enard W. Autosomal recessive primary microcephaly (MCPH): a review of clinical, molecular, and evolutionary findings. Am J Hum Genet 2005;76:717-28. doi:10.1086/429930

60 Honein MA, Dawson AL, Petersen EE, et al. US Zika Pregnancy Registry Collaboration. Birth Defects Among Fetuses and Infants of US Women With Evidence of Possible Zika Virus Infection During Pregnancy. JAMA 2017:317:59-68. doi:10.1001/jama.2016.19006

61 Johansson MA, Mier-y-Teran-Romero L, Reefhuis J, Gilboa SM, Hills SL. Zika and the Risk of Microcephaly. N Engl J Med 2016;375:1-4. doi:10.1056/NEJMp1605367

62 Miller E, Cradock-Watson JE, Pollock TM. Consequences of confirmed maternal rubella at successive stages of pregnancy. Lancet 1982;2:781-4. doi:10.1016/S0140-6736(82)92677-0

63 Cuevas EL, Tong VT, Rozo N, et al. Preliminary Report of Microcephaly Potentially Associated with Zika Virus Infection During Pregnancy - Colombia, January-November 2016. MMWR Morb Mortal Wkly Rep 2016:65:1409-13. doi:10.15585/mmwr.mm6549e1

64 Luteijn JM, Brown MJ, Dolk H. Influenza and congenital anomalies: a systematic review and meta-analysis. Hum Reprod 2014;29:809-23. doi:10.1093/humrep/det455

65 Torgerson PR, Mastroiacovo P. The global burden of congenital toxoplasmosis: a systematic review. Bull World Health Organ 2013;91:501-8. doi:10.2471/BLT.12.111732

66 Wijesooriya NS, Rochat RW, Kamb ML, et al. Global burden of maternal and congenital syphilis in 2008 and 2012: a health systems modelling study. Lancet Glob Health 2016;4:e525-33. doi:10.1016/S2214-109X(16)30135-8

67 van Zuylen WJ, Hamilton ST, Naing Z, Hall B, Shand A, Rawlinson WD. Congenital cytomegalovirus infection: Clinical presentation, epidemiology, diagnosis and prevention. Obstet Med 2014;7:140-6. doi:10.1177/1753495×14552719

\section{Supplementary table}

